DE GALICIA, ESPAÑA E MÁIS ALÁ Historia da educación. Novas de Galicia (2013)

Durante 2013 defendéronse na Universidade de Santiago tres teses de doutoramento relacionadas coa historia da educación en Galicia. Dúas delas relacionadas coa cidade de Vigo presentadas polas profesoras Miriam Varela Iglesias (Educación institucional y Sociedad en Vigo en el siglo XIX) e por María Fernanda Piñero Sampayo ( $L a$ acción educativa de los colegios religiosos femeninos en La ciudad de Vigo,18861962), e unha sobre a historia curricular da educación física na cidade de Compostela, da autoria de Xosé L. Antas Ramos, $O$ processo de construción dunha disciplina escolar no Instituto de Santiago e na cidade de Compostela: da ximnástica á educación física (1893-1936).

O Album da Ciencia, que promove mediante edición dixital o Consello da Cultura Galega, é un ambicioso e novidoso proxecto que ten como punto de partida as 201 biografías elaboradas para un anterior Diccionario histórico de científicos galegos por parte do Grupo de Traballo de Historia das Ciencias desde o momento da súa constitución, en 1987, como área do Seminario de Estudos Galegos, e que contou co antecedente do Album da ciencia xerado en 2007 en conmemoración do centenario da JAE. Agora, o principal criterio utilizado para a selección de autores é o da relevancia da obra no momento histórico que viviron e o seu vínculo con Galicia. $O$ resultado final permitirá ofrecer un total dunhas 300 entradas online, unha parte substancial do I+D histórico do país, unha especie de panteón virtual da excelencia científica que proporcionará unha valiosa e actualizable información a públicos diversos.A elaboración desta nova versión do Álbum da Ciencia realízase mediante a participación dun amplo equipo de especialistas, baixo a dirección de Xosé A. Fraga Vázquez, da Sección de Ciencia, Natureza e Sociedade do Consello, quen contou coa colaboración do coordinador desa Sección, Francisco Díaz-Fierros Viqueira, na codirección, e de Alfonso Mato na coordinación e redacción, debendo anotar a notable importancia que ten para os estudos de historia da educación en Galicia, dada a mesma cualificación como profesores dunha altísima porcentaxe dos nomes inscritos neste Album ( http://www. culturagalega.org/albumdaciencia/)

A Fundación Barrié que promove a canle de televisión "Barrié educa" convocou em 2013 o Primeiro concurso sobre "A historia das escola em Galicia: a escola dos meus avós", no que participaron mais de 50 colexios de toda Galicia, que o fixeron preferentemente en galego, ben que 0 lanzamento da iniciativa privilexia a língua castelá, que era a da escola franquista, aínda que non a maioritaria dos rapaces e rapazas que a ela acodían. Os resultados primeiros permitiron recoller testemuños interesantes que, por outra parte, achegan aos escolares de hoxe materiais gráficos e voces con notable contido histórico. O profesor Xosé Manuel Domínguez de Pontedeume foi un dos coordenadores desta iniciativa (http://www.educabarrie. org/proyectos $/ \%$ E2 $\% 80 \% 9 \mathrm{C}$-i-concursode-historia-de-la-escuela-en-galicia-laescuela-de-mis-abuelos).

O Museo Pedagóxico de Galicia, despois dun tempo de certo silencio, recuperou unha maior actividade. As, í xunto 
á recepción constante de visitantes, moitos deles en grupos, e a súa contribución de prestamo de obxectos e libros para distintas iniciativas culturais, volveu realizar exposicións temporais, facendoo mediante unha relacionada co uso de materiais e recursos didácticos visuais ao servizo da chamada pedagoxía intuitiva, tan solicitada como iniciativa de renovación didactica no tempo de finais do século XIX e comezos do XX: a beira de tantos obxectos (con máquinas de cine e microscópios, entre outros) é de destacar a notable colección de láminas de parede, particularmente relacionadas coa historia natural. Nos momentos actuais O MUPEGA celebra outra exposición temporal, nesta ocasión relacionada coa pedagoxía e as escolas despois de 1970, o ano de aprobación da Lei Xeral de Educación.

A Sala de exposicións do Colexio Fonseca acolleu en Santiago de Compostela no pasado Outono a exposición Enclave diversa que mostraba unha atención particular aos libros e obxectos para nenos: a colección "OrtegaGutierrez Baños" de libros despregables, a colección de Principiños de Saint$d^{\prime}$ Exupery en diversas línguas que reuniu o escritor Carlos Casares, unha colección de Tintin's creada por Pedro Rey e as variedades e marabillas do mundo de Alicia de Lewis Carroll, composta por Fátima García Doval. Em canto aos libros despregables puidemos ver 'libros-tunel' 'farois de papel', 'ruletas', 'troquelados', 'articulacións', 'imaxes combinadas e transformables', 'teatriños' e outros híbridos entre libros e xoguetes creados en distintos lugares de Europa e América: desde as Harlequinades de Philaddelphia (1788), ou o Telescopic View of the Great Exhibition de
Londres (1851), pasando polas creacións de Ernest Nister, Lothar Meggensdorfer, Raphael Tuck, Louis Giraud ou Harold Lent, ata chegar as máis recentes creacións de Julian Wehr e de Geraldine Klyne.

O Consello da da Cultura Galega coa colaboración e axuda da Secretaría Xeral da Emigración da Xunta de Galicia veñen levando a cabo diversas iniciativas de investigación e recuperación sobre a emigración en América. Esta parcería fixo posible, entre outros proxectos, a catalogación das construcións escolares financiadas polos emigrantes nas catro provincias galegas, que agora culminou nunha nova exposición, comisariada polo profesor Vicente Peña Saavedra, quen contou coas documentalistas Carolina Gacía Borrazás e Mํㅜ T. García Domínguez, permitindo mostrar, a dimensión da efeméride do centenario fundacional das Sociedades Galegas de Instrución radicadas en América e, doutra, as súas realizacións académicas nas localidades de procedencia dos emigrantes. Un catálogo de acceso directo permite manter a memoria desta exposición: Luces de Alén Mar. As escolas de americanos en Galicia (Edición revisada e ampliada)

http://www.consellodacultura.org/ mediateca/extras/cat luces alen mar.pdf

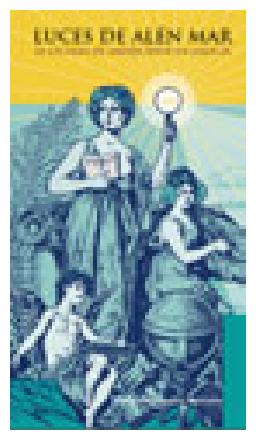


É do caso sinalar dentro destas Novas que o profesor da Universidade de Santiago e membro do Consello editorial desta publicación Dr. Antón Costa Rico concluíu o seu mandato como Presidente da Sociedade Española de Historia da Educación (http://www.sc.ehu.es/ sfwsedhe/), con ocasión do XVII Coloquio Español de Historia de la Educación celebrado na Universidade de Cádiz no mes de Xullo de 2013. Dentro da renovación democrática de responsabilidades desta Sociedade Española foi elixida Presidenta a profesora Dra. Gabriela Ossenbach da UNED (Madrid), e en calidade de Vicepresidente o tamén profesor galego da Facultade de Formación do Profesorado de Lugo Dr. Uxío Otero Urtaza, igualmente membro do Consello editorial de Sarmiento.

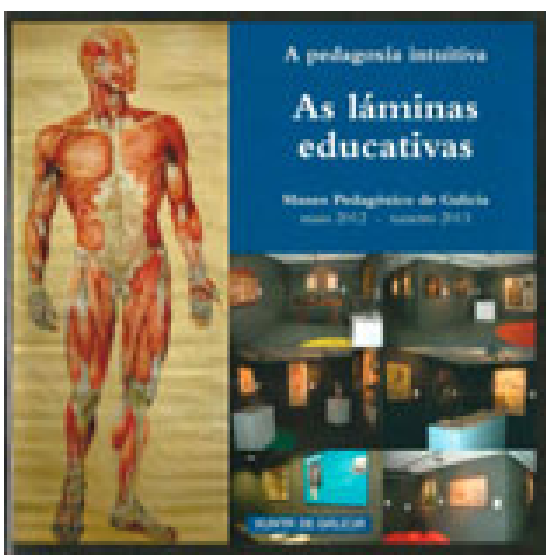

Castro Fustes, Emilio y Cepeda Fandiño, Antonio (textos); Seco González, Beatriz (fotografías), A pedagoxía intuitiva. As láminas educativas. Santiago de Compostela, MUPEGA / Xunta de Galicia / Consellería de Cultura, Educación e Ordenación Universitaria, 2013, 42 pp.

\section{A História da Educação em Portugal 2011-2013}

Este espaço que a Revista Sarmiento dedica às atividades desenvolvidas pela comunidade portuguesa de História da Educação constitui uma iniciativa importante, que começou em números anteriores e permite divulgar o que se fez ao longo do triénio de 2011-2013. Desta forma consolida-se o intercâmbio ibérico entre as duas comunidades académicas, marcado simultaneamente pelo conhecimento mútuo e o aprofundamento de amizades, tecidos na teia de encontros científicos, de projetos e de publicações conjuntas e também na geografia dos afetos que marcaram este relacionamento entre os elementos dos dois grupos. Compreendese assim a proximidade nos temas e objetos de investigação e a construção de um discurso científico que traduz essa proximidade e cooperação.

Os três anos de que se ocupa este texto correspondem à coordenação da Secção de História da Educação pela sua autora, o que representa uma responsabilidade acrescida quanto ao seu conteúdo. Nas opções que necessariamente têm de se tomar, delinearam-se os tópicos a abordar: os congressos e outros encontros de natureza científica que se realizaram em Portugal ou nos quais a participação de investigadores portugueses foi significativa; os projetos que marcaram a atividade desenvolvida pelos mesmos investigadores; e as publicações que divulgam o conhecimento produzido.

As notícias sobre a comunidade de História da Educação de Portugal podem ser consultadas na sua página on line, que se encontra no endereço: http://www. sophe.pt 